\title{
Penentuan Faktor Kelayakan Penerimaan Karyawan Menggunakan Algoritma Decission Tree pada Perusahaan PT. Personel Alih Daya
}

\author{
Deni Anugrah Sahputra ${ }^{1)}$, M Rangga Ramadhan Saelan²), \\ Lilyani Asri Utami ${ }^{3)}$, Windu Gata ${ }^{4)}$ \\ ${ }^{122) 344)}$ Program Studi Magister Ilmu Komputer, STMIK Nusa Mandiri \\ Jl. Kramat Raya No.18, Jakarta Pusat, Jakarta \\ 1)14002345@nusamandiri.ac.id \\ 2)14002400@ nusamandiri.ac.id \\ 3) lilyani.lau@nusamandiri.ac.id \\ 4)windu@ nusamadiri.ac.id
}

\begin{abstract}
Abstrak
Kebutuhan pekerjaan yang semakin meningkat, membuat pelamar pekerjaan semakin meningkat[2]. PT Personel Alih Daya (PERSADA) adalah salah satu outsourcing di Indonesia yang sudah memiliki 19 kantor cabang. membutuhkan banyak kandidat untuk pemenuhan tenaga kerja di Mitra. oleh karena itu diadakan walkin interview dari hari Senin sampai dengan Jumat. Untuk mendapatan tenaga kerja yang memenuhi standar kualifikasi mitra. Pelamar kerja yang datang (walk in interview) ke PT Personel Alih Daya (PERSADA) rata-rata mencapai 50 orang setiap harinya. Untuk memaksimalkan penentuan kelayakan penerimaan tenaga kerja, serta terpenuhnya kebutuhaan tenaga kerja semakin cepat, maka diperlukannya sebuah prediksi cepat untuk mengetahui kelayakan penerimaan karyawan menggunakan algoritma decission tree pada perusahaan PT. Personel Alih Daya. Untuk menentukan kelayakan tenaga kerja baru bisa di klasifikasikan dengan cepat menggunakan prediksi berdasarkan kriteria paling berpengaruh dalam menentukan kelayakan penerimaan karyawan. dilakukan dengan menggunakan metode C4.5 artibut yang digunakan dalam penelitian tersebut berdasarkan umur, domisili, jenis kelamin, Posisi kerja, jurusan, referensi, level pendidikan dan hasil test. Dengan algoritma tersebut menghasilkan angka akurasi 73,27 serta dengan angka curva AUC 0,789.
\end{abstract}

Kata kunci: Penerimaan Karyawan, Data Mining, Decission Tree.

\begin{abstract}
Job needs are increasing, making job applicants increasing [2]. PT Personnel Alih Daya (PERSADA) is one of the outsourcing companies in Indonesia which has 19 branch offices. Requires a lot of candidates to meet the work needs of Partners. therefore a walkin interview is held from Monday to Friday. To get workers who meet the partner qualification standards. Job applicants who come (walk in interviews) to PT Persel Alih Daya (PERSADA) on average reach 50 people each meeting. To maximize the eligibility of workforce recruitment, and to meet the needs of the workforce more quickly, the need for a quick scramble to obtain eligibility for employee recruitment using a company decision-making algorithm at PT. Personal Outsourcing. To determine the feasibility of a new workforce can be classified quickly using an assessment based on the best criteria in determining the eligibility of employee recruitment. Done using the C4.5 artibut method used in this study based on age, domicile, gender, work position, majors, references, education level and test results. With this algorithm produces 73.27 and AUC 0.789 curves.
\end{abstract}

Keywords: Employee Reception, Data Mining, Decission Tree. 


\section{PENDAHULUAN}

Kehidupan dan pekerjaan adalah dua sisi mata uang, agar manusia dapat hidup maka manusia harus bekerja. Manusia sebagai mahluk sosial (zoon politicon) mempunyai kebutuhan yang beraneka ragam, yang diantaranya adalah sandang, papan, pangan. Demi terpenuhinya berbagai kebutuhan itu manusia dituntut untuk bekerja karena dengan pekerjaanya itu dapat diperoleh suatu penghasilan [1]. Kebutuhan pekerjaan yang semakin meningkat, membuat pelamar pekerjaan semakin meningkat. Dalam pencarian informasi lowongan pekerjaan, pelamar biasanya masih menggunakan cara-cara konvensional, yaitu dengan mendatangi perusahaan untuk melihat papan pengumuman yang berisi lowongan pekerjaan, melakukan pencarian di media cetak seperti koran, majalah, brosur atau dengan informasi dari mulut ke mulut[2]. Informasi lowongan pekerjaan merupakan salah satu kebutuhan bagi masyarakat. Informasi selama ini diberikan hanya melalui pengumuman di media cetak dan kantor ketenagakerjaan [3].Saat ini hampir semua perusahaan meng-alih dayakan (outsourcing) pegawainya sehingga banyak pelamar kerja yang difungsi tugaskan menjadi karyawan outsourcing sesuai dengan Peraturan Mentri tenaga Kerja (Permenaker) No 5 Tahun 1995 dan Peraturan Menteri tenaga Kerja No 2 tahun 1993, kebijakan ini langsung di terbitkan oleh peraturan presiden [4]. Oleh sebab itu banyak outsource berlombalomba mencari sebanyak - banyaknya calon tenaga kerja untuk disalurkan ke perusahan perusaaahan yang bekerja sama dengan outsourcing tersebut dengan harapan menjadi benefit tersendiri sesuai kontrak kerjasama kedua perusahaan tersebut. Departemen Tenaga Kerja dan Transmigrasi yang mendefinisikan pengertian outsourcing (alih daya) sebagai memborongkan satu bagian atau beberapa bagian kegiatan perusahaan yang tadinya dikelola sendiri kepada perusahaan lain yang kemudian disebut sebagai penerima pekerjaan [5].

PT Personel Alih Daya (PERSADA) adalah salah satu outsourcingdi Indonesia yang sudah memiliki 19 kantor cabang. PT Personel Alih Daya (PERSADA) saat ini sudah memiliki 4 (empat) Bisnis Unit, diantaranya yaitu Technical Services, Office Services, Security Services, dan Customer Care Center. PT Personel Alih Daya (PERSADA) membutuhkan banyak kandidat untuk pemenuhan tenaga kerja di Mitra. Perusahaan harus mampu mengelola sumber daya manusia dengan baik [6]. oleh karena itu diadakan walkin interview dari hari Senin sampai dengan Jumat. Untuk mendapatan tenaga kerja yang memenuhi standar kualifikasi mitra. Pelamar kerja yang datang (walk in interview) ke PT Personel Alih Daya (PERSADA) rata-rata mencapai 50 orang setiap harinya. Penerimaan pegawai baru atau rekrutmen adalah hal yang paling penting bagi perusahaan untuk memperoleh calon pegawai baru dalam menduduki suatu jabatan. Karyawan adalah aset utama perusahaan yang menjadi perencana dan pelaku aktif dari aktivitas organisasi [7].

Berdasarkan hasil dari pembahasan diatas, Untuk memaksimalkan penentuan kelayakan penerimaan tenaga kerja, serta terpenuhnya kebutuhaan tenaga kerja semakin cepat, maka diperlukannya sebuah prediksi cepat untuk mengetahui kelayakan penerimaan karyawan menggunakan algoritma decission tree pada perusahaan PT. Personel Alih Daya. Untuk menetukan kelayakan tenaga kerja baru bisa di klasifikasikan dengan cepat menggunakan prediksi berdasarkan kriteria paling berpengaruh dalam menentukan kelayakan penerimaan karyawan. Untuk mendapatkan prediski berdasarkan kriteria paling berpengaruh maka data tarikan dari Employee Recruitment System (ERS) pada PT. Personel Alih Daya satu tahun yang lalu digunakan sebagai bahan penelitian menggunakan data mining untuk memprediksikan kelayakan calon tenaga kerja berdasarkan umur, domisili, jenis kelamin, Posisi kerja, jurusan, referensi, level pendidikan dan hasil test yang mempengaruhi kelayakan penerimaan karyawan.

\section{TINJAUAN PUSTAKA}

\subsection{Penelitian Terkait}

Penentuan penerimaan karyawan sebelumnya sudah pernah dilakukan dengan menggunakan metode C4.5 artibut yang digunakan dalam penelitian tersebut diantaranya usia, pendidikan, pengalaman dan kepemilikan kendaraan didapatkan hasilnya nilai akurasi $71,54 \%$ dengan angka curva ROC $0,721[8]$. 
Dalam penelitian tersebut terdapat perbedaan atribut yang dilakukan penelitian ini antara lain umur, domisili, jenis kelamin, Posisi kerja, jurusan, referensi, level pendidikan dan hasil test. Terdapat perbedaan hasil. Sehingga niali akurasi lebih tinggi sebesar 73,27\%. Hasil penelitian ini bisa menjadi tolak ukur yang tepat dari nilai akurasi yang dihasilkan dengan proses pengolahaan data dari sebelumnya.

\subsection{Data Mining}

Data mining telah menarik banyak perhatian dalam dunia sistem informasi dan dalam masyarakat secara keseluruhan dalam beberapa tahun terakhir, karena ketersediaan luas dalam jumlah besar data dan kebutuhan segera untuk mengubah data tersebut menjadi informasi yang berguna dan pengetahuan. Data mining adalah untuk mengekstrasikan atau "menambang" pengetahuan dari kumpulan banyak data[9]. Sehingga dapat dilakukan proses mining untuk memprediksikan kelayakan tenaga kerja secara efesien dan proses penerimaan karyawan baru menjadi lebih cepat disalurkan ke mitra yang berkerja sama dengan PT. Personel Alih Daya.

\subsection{Algoritma Decission Tree}

Penelitian ini untuk mengetahui lulus atau tidak lulus calon tenaga kerja, maka penelitian menggunakan Algoritma Decission Tree berdasarkan umur, domisili, jenis kelamin dan level pendidikan sebagai variabel pendukung dalam penelitian. Jenis Algoritma Decission Tree yang digunakan yaitu Algoritma C4.5. Algoritma C4.5 merupakan algoritma yang dikembangkan dari algoritma ID3. C4.5 ini merupakan algoritma turunan dari algoritma ID3 dengan beragam peningkatan. Beberapa peningkatan ini diantaranya adalah, penanganan atribut-atribut numerik, missing value dan noise pada dataset, dan aturan- aturan yang dihasilkan dari model pohon yang terbentuk [10].

\section{METODE PENELITIAN}

Penelitian Data Mining ini menggunakan metodologi standar yang disebut CRISP-DM atau Cross-Industry Standard Process for Data Mining. CRISP-DM merupakan hasil kolaborasi dari beberapa perusahaan, diantaranya Daimler-Benz, OHRA, NCR Corp., dan SPSS Inc. yang mulai dirintis sejak tahun 1999. CRISP-DM memiliki enam tahapan, berikut penjelasannya [10]:

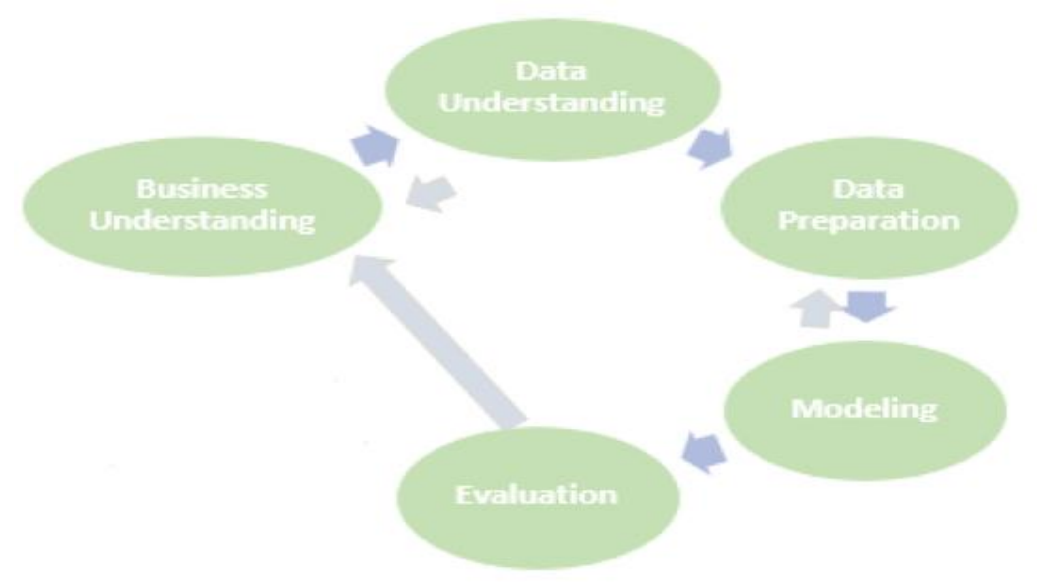

Gambar 1. Siklus CRISP-DM

\subsection{Business Understanding}

Pada tahapan pertama ini harus didefinisikan apa pengetahuan yang ingin didapatkan dalam bentuk pertanyaan-pertanyaan yang sifatnya umum.[10] Pada penelitian ini mencoba menentukan tujuan dari penelitian untuk mendapatkan tenaga kerja yang memiliki potensi dengan kriteria yang diinginkan dengan menentukan kelayakan penentuan faktor kelayakan penerimaan karyawan menggunakan algoritma decission tree pada perusahaan PT. Personel Alih Daya 


\subsection{Data Understanding}

Tahapan kedua ini bertujuan untuk mengumpulkan, mengidentifikasikan, dan memahami aset data yang kita miliki. Data tersebut juga harus dapat diverifikasi kebenaran dan realibilitasnya [10]. Pada tahapan ini menumpulkan data dengan cara menarik data dari Employee Recruitment System (ERS) pada PT. Personel Alih Daya. dari sistem Employee Recruitment System (ERS) terdapat biodata kandidat, hasil test psikotes dan hasil dari interview.

\subsection{Data Preparation}

Tahapan ini meliputi banyak kegiatan, seperti membersihkan data, memformat ulang data, mengurangi jumlah data, dan sebagainya yang bertujuan untuk menyiapkan data agar konsisten sesuai format yang dibutuhkan [10]. Pada penelitian jumlah yang diteliti sebanyak 19163 data. Peneiti melakukan penyeleksian data menggunakan software RapidMiner.

\subsection{Modeling}

Model adalah representasi komputasi dari hasil pengamatan yang merupakan hasil dari pencarian dan identifikasi pola-pola yang terkandung pada datas[10]. Pada tahap modeling dalam data mining dengan menggunakan algoritma dengan parameter nilai yang optimal. Pada penelitian ini model algoritma yang digunakan yaitu algoritma Decission Tree, Jenis Algoritma Decission Tree yang digunakan yaitu Algoritma C4.5

\subsection{Evaluation}

Evaluasi bertujuan untuk menentukan nilai kegunaan dari model yang telah berhasil kita buat pada langkah sebelumnya [10]. Pada tahap evaluation dilakukan proses klasifikasi algoritma dengan menguji tingkat akurasi dari algoritma Decission Tree

\section{HASIL DAN PEMBAHASAN \\ 4.1 Business Understanding}

Business Understanding pada tahapan ini adalah dataset yang diperoleh dari hasil tarikan data Employee Recruitment System (ERS) pada PT. Personel Alih Daya satu tahun yang lalu digunakan sebagai bahan penelitian yang diperoleh "Lulus" atau "Tidak Lulus" dengan memprediksikan kelayakan calon tenaga kerja berdasarkan umur, domisili, jenis kelamin dan level pendidikan. Untuk menetukan kelayakan tenaga kerja baru bisa di klasifikasikan dengan cepat menggunkan prediksi berdasarkan kriteria paling berpengaruh dalam menentukan kelayakan penerimaan karyawan. sehingga hasil dari kriteria paling berpengaruh terhadap kelayakan tenaga kerja secara efesien dan proses penerimaan karyawan baru menjadi lebih cepat di salurkan ke mitra yang berkerja sama dengan PT. Personel Alih Daya. Pada pembahasan ini penulis tertarik untuk membuat klasifikasi terhadap kelayakan penerimaan karyawan yang memiliki pengaruh lulus dan tidak lulus.

\subsection{Data Understanding}

Data understanding merupakan dataset yg diambil dari Employee Recruitment System (ERS) pada PT. Personel Alih Daya satu tahun yang lalu digunakan sebagai bahan penelitian. Variabel input dari dataset yang diambil sebanyak 7 attribut yaitu kandidat dari posisi yang dilamar, Jenis kelamin kandidat, umur kandidat, domisili kandidat, level pendidikan kandidat, Jurusan pendidikan kandidat, referensi kandidat, untuk lebih jelas bisa dilihat dari tabel 1 dibawah ini:

Tabel 1. Atribut

\begin{tabular}{ll}
\hline \multicolumn{1}{c}{ Nama Atribut } & \multicolumn{1}{c}{ Keterangan } \\
\hline & (Technical Services, Office Services, Security Services, Customer Care \\
Posisi yang dilamar & Center) Kategori \\
Jenis kelamin kandidat & (Pria dan Wanita) Kategori \\
\hline
\end{tabular}


Umur kandidat

Domisili kandidat

Level pendidikan kandidat

Referensi kandidat
(16-64) kategori

(NSA, SSA, Jabodetabek, WJA, CJA, EJBN, Kalimantan, Sumapa)

Kategori

(SMP, SMA/K, DI, DII, DIII, S1, S2, S2) Kategori

(Media Sosial, Temen, Koran, Inisiatif Sendiri Website) Kategori

\subsection{Data Preparation}

Data Preparation pada tahap ini adalah proses mempersiapkan data sehingga data siap digunakan. Persiapan data yang dilakukan mulai dari pengkategorian terhadap beberapa atribut diantaranya pengkategorian umur yang awalnya memiliki rentang nilai 16-64 tahun menjadi beberapa kategori yaitu $<25$ tahun, 26-30 tahun, 31-35 tahun dan $>60$ tahun, dimana dalam pengkategorian ini tetap mencakup seluruh data yakni 16-64 tahun. Selanjutnya Pengkategorian dilakukan berdasarkan jenis kelamin ada pria atau wanita, Selanjutnya Pengkategorian dilakukan berdasarkan domisili menjadi beberapa kategori diantaranya North of Sumatera (NSA), South of Sumatera (SSA), Jabodetabek, West Java Area (WJA), Central Java Area (CJA), East Java Bali Nusa (EJBN), Kalimantan dan Sulawesi Maluku dan Papua (Sumapa) kategori tersebut berdasarkan kebutuhan tenaga kerja di masing-masing kantor Cabang PT. Personel Alih Daya dan pengkategorian terakhir berdasarkan level pendidikan atribut ini dikategorikan menjadi SMP, SMA/K, Diploma, Sarjana dan beberapa kategori lainya yang mempengaruh kelayakan penerimaan karyawan, karena jumlah data yang terlalu banyak dan beragam membuat data tersebut sulit untuk dipahami. Untuk lebih jelasnya berikut merupakan tabel pengkategorian pada data Employee Recruitment System (ERS) yang dimuat pada Tabel 2 berikut.

Tabel 2. Kategori

\begin{tabular}{|c|c|c|}
\hline Nama Atribut & Keterangan & Sumber \\
\hline Posisi yang dilamar & $\begin{array}{l}\text { Technical Services } \\
\text { Office Services } \\
\text { Security Services } \\
\text { Customer Care Center }\end{array}$ & PT. Personel Alih Daya \\
\hline Jenis kelamin kandidat & $\begin{array}{l}\text { Pria } \\
\text { Wanita }\end{array}$ & PT. Personel Alih Daya \\
\hline Umur & $\begin{array}{l}<25 \\
26-30 \\
31-35 \\
36>\end{array}$ & [11] \\
\hline Domisili kandidat & $\begin{array}{l}\text { North of Sumatera Area } \\
\text { South of Sumatera Area } \\
\text { Jabodetabek } \\
\text { West Java Area } \\
\text { Central Java Area } \\
\text { East Java Bali Nusa } \\
\text { Kalimantan } \\
\text { Sulawesi Maluku dan Papua }\end{array}$ & PT. Personel Alih Daya \\
\hline Level pendidikan kandidat & $\begin{array}{l}\text { SMP } \\
\text { SMA/ K } \\
\text { Diploma } \\
\text { Sarjana }\end{array}$ & PT. Personel Alih Daya \\
\hline Referensi kandidat & $\begin{array}{l}\text { Media Sosial } \\
\text { Temen } \\
\text { Koran } \\
\text { Inisiatif Sendiri } \\
\text { Website }\end{array}$ & PT. Personel Alih Daya \\
\hline
\end{tabular}




\subsection{Modeling}

Modeling pada tahapan ini dilakukan setelah semua data telah bisa digunakan. Pemodelan ini dilakukan dengan menerapkan algoritma decission tree. Pada proses pencarian hasil evaluasi dengan mendapatkan akurasi yang baik digunakan dengan pengolahan yang dilakukan dengan algoritma decission tree dengan menggunakan model Cross Validation.

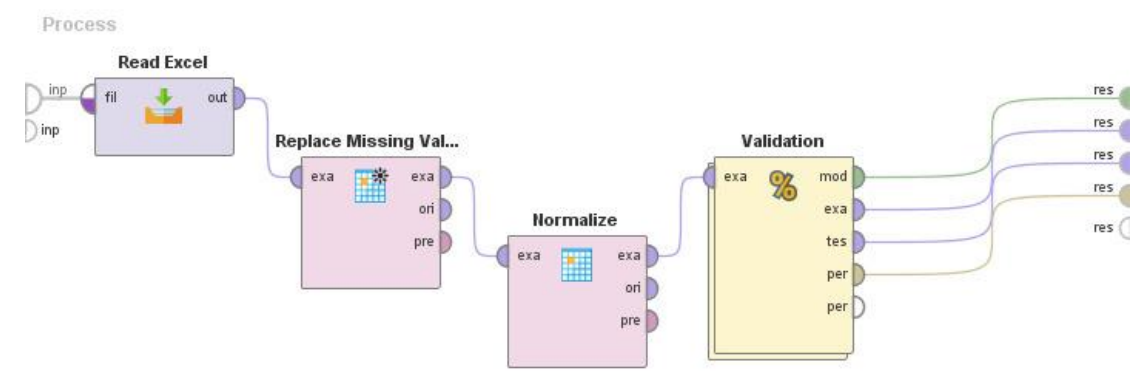

Gambar 2. Tahap pemodelan data

Pada tahapan gambar di atas penelitian menggunakan algoritma decission tree untuk memproses data yang akan di olah. Penerapan model yang menggunakan model Cross Validation, seperti pada gambar di bawah ini:

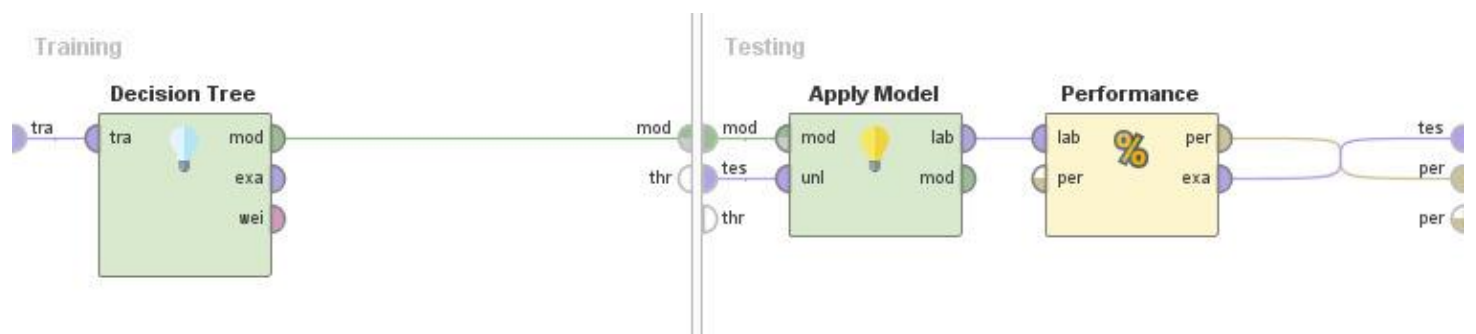

Gambar 3. Model Cross Validation

Pada tahapan gambar diatas merupakan operator yang melakukan validasi silang dan perlu seperangkat contoh masukan yang berlabel. Secara default, Validasi silang membagi data menjadi 10 bagian yang berbeda, jadi kita menyebutnya validasi silang 10 kali lipat. Pada cross validation menunjukkan dua sub-proses yanb berisi training dan testing dimana terdapat data training berupa model decision tree kemudian data testing berupa apply model dan performance.

\subsection{Evaluation}

Hasil dari pengujian dengan agoritma Decission Tree, akurasi yang didapatkan dari tampilan dalam tabel Confusion Matrix nilai accurancy sebagai berikut.

\begin{tabular}{|c|c|c|c|}
\hline \multicolumn{4}{|c|}{ accuracy: $73.27 \%+l-0.67 \%$ (micro average: $73.27 \%$ ) } \\
\hline & true Lulus & true Tidak Lulus & class precision \\
\hline pred. Lulus & 7042 & 4869 & $59.12 \%$ \\
\hline pred. Tidak Lulus & 253 & 6999 & $96.51 \%$ \\
\hline class recall & $96.53 \%$ & $58.97 \%$ & \\
\hline
\end{tabular}

Gambar 4. Nilai Accurancy Cross Validation 
Berdasarkan gambar diatas, dapat dilihat hasil akurasi yang dihasilkan sebesar 73,27\%. Hal tersebut menujukan hasil akurasi yang dihasilkan dalam kategori baik. Pada model cross validation menghasilkan nilai $A U C$ sebesar 0,789 dimana dalam grafik $R O C$ yang dapat diketahui pada gambar berikut.

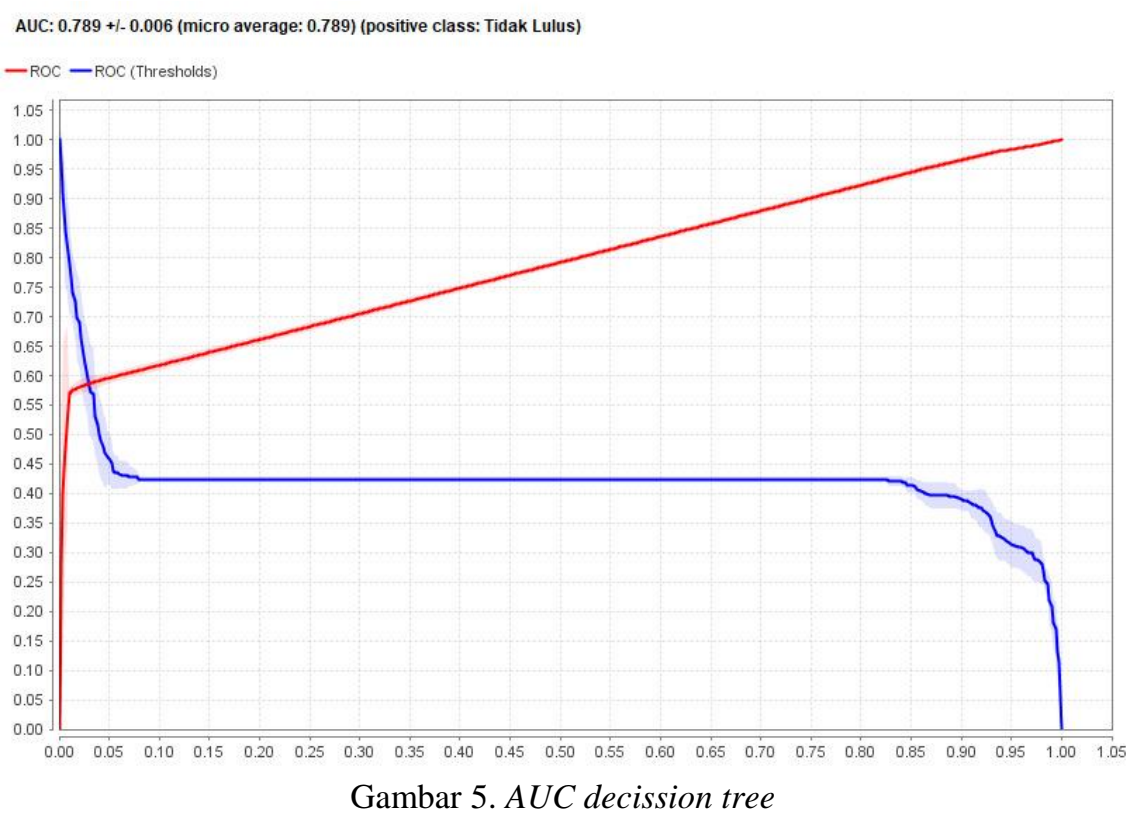

Berdasarkan hasil diatas dapat dilihat hasil terbaik digambarkan pada table dibawah ini.

Tabel 3. Hasil uji Konversi Data Kedalam Kategorikal

\begin{tabular}{ll}
\hline & Cross Validation \\
\hline Accurancy & $73,27 \%$ \\
AUC & 0,789 \\
\hline
\end{tabular}

Dari tabel diatas untuk mengetahui kelayakan penerimaan karyawan baru menggunakan algoritma decission tree dengan model cross validation memiliki nilai accuracy yang tinggi sebesar 73,27\% dengan nilai $A U C$ yaitu 0,789

\section{KESIMPULAN}

Berdasarkan hasil penelitian yang telah dilakuan dengan software Rapidminer terhadap dataset penentuan faktor kelayakan penerimaan karyawan pada PT. Personel Alih Daya yang diperoleh dari Employee Recruitment System (ERS) dengan jumlah data sebesar 19163 kandidat yang melamar kerja pada tahun 2019 dengan menggunakan algoritma Decission Tree menghasilkan Accurancy Sebesar 73,27\% dan nilai AUC 0,789. Faktor kelayakan penerimaan karyawan pada PT. Personel Alih Daya yang paling berpengaruh yaitu pada referensi dari teman, umur dari 26 sampai dengan 30, jenis kelamin wanita, posisi yang di lamar Office Services, berdomisili Jabodetabek dan level berpendidikan sarjana. disimpulkan hasil penelitian ini dapat memberikan rekomendasi kepada PT. Personel Alih Daya dalam menentukan calon tenaga kerja sesuai dengan kriteria yang dibutukan oleh klien. 


\section{DAFTAR PUSTAKA}

[1] S. Kunarti, "Perjanjian Pemborongan Pekerjaan ( Outsourcing)," J. Chem. Inf. Model., vol. 5, no. 3, pp. 67-76, 2006.

[2] M. Safitri, A. Novianti, A. Noviriandini, T. Informatika, and I. Komputer, "Sistem informasi lowongan kerja berbasis web," vol. 14, no. 1, pp. 49-54, 2018.

[3] D. W. T. PUTRA and J. J. PUTRA, "Perancangan Sistem Informasi Pencarian Lowongan Pekerjaan,” J. Teknoif, vol. 6, no. 1, pp. 48-54, 2018, doi: 10.21063/jtif.2018.v6.1.48-54.

[4] J. Pangaribuan, "Legalitas Outsourcing Pasca Putusan MK Oleh: Juanda Pangaribuan | Article \&amp; Event | SDM9," 2015. [Online]. Available: http://www.sdm9.co.id/Articleand-Event/Legalitas-Outsourcing-Pasca-Putusan-MK-Oleh-Juanda-Pangaribuan.html. [Accessed: 23-Jul-2018].

[5] G. L. Puspita and M. Affandi, "Analisis Penyaluran Tenaga Kerja Oleh PerusahaanPerusahaan Outsourcing Di Perusahaan Airlines ( Studi Kasus Di Pt Mandala Airlines )," J. Ilmu Ekon. dan Pembang., vol. 15, no. 2, pp. 56-70, 2015.

[6] E. Sukmana and G. Sudibia, "Pengaruh Kepemimpinan Transformasional, Motivasi Dan Burnout Terhadap Kinerja Karyawan Outsourcing Rri Mataram," E-Jurnal Manaj. Univ. Udayana, vol. 4, no. 8, p. 255319, 2015.

[7] Y. Siagian, "Seleksi Penerimaan Karyawan Baru Menggunakan," J. Mantik Penusa, vol. 2, no. 1, pp. 65-70, 2018.

[8] P. T. Prismas, J. Jakarta, A. Asistyasari, and T. Baidawi, "ANALISIS PENERIMAAN KARYAWAN POSISI FIELD COLLECTOR MENGGUNAKAN ALGORITMA C4 . 5 PADA," vol. 2, no. 2, pp. 1-6, 2017.

[9] W. D. Septiani, "Dan Naive Bayes Untuk Prediksi Penyakit Hepatitis," vol. 13, no. 1, pp. 76-84, 2017.

[10] I. Sutoyo, "Implementasi Algoritma Decision Tree Untuk Klasifikasi Data Peserta Didik," J. Pilar Nusa Mandiri, vol. 14, no. 2, p. 217, 2018, doi: 10.33480/pilar.v14i2.926.

[11] R. D. Sitepu and E. Buulolo, "Implementasi Algoritma Nearest Neighbor Pada Penerimaan," vol. I, no. 1, pp. 256-263, 2017.

\section{Biodata Penulis}

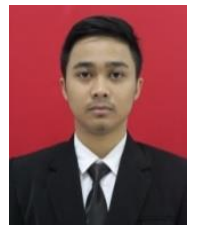

Deni Anugrah Sahputra, Jakarta / 28 Januari 1994. Penulis menyelesaikan Studi Strata 1 (S1) di Kampus Stmik Nusa Mandiri Jakarta dengan Jurusan Sistem Informasi dengan gelar S.Kom di tahun 2017 dan sedang melanjutkan Studi Strata (S2) di Pascasarjana STMIK Nusa Mandiri Depok dengan jurusan Ilmu Komputer. Penulis berkerja di PT. Personel Alih Daya Jakarta sebagai Staff HRD.

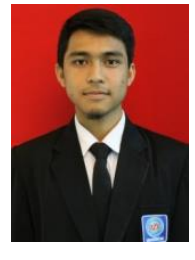

M. Rangga Ramadhan Saelan, Sukabumi / 01 Januari 1998. Penulis menyelesaikan Studi Strata 1 (S1) di Kampus Universitas Bina Sarana Informatika Sukabumi dengan Jurusan Sistem Informasi dengan gelar S.Kom di tahun 2017 dan sedang melanjutkan Studi Strata (S2) di Pascasarjana STMIK Nusa Mandiri Depok dengan jurusan Ilmu Komputer. Penulis berkerja di STMIK Nusa Mandiri sebagai Tenaga Pengajar.

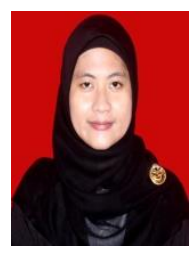

Lilyani Asri Utami, lahir di Bogor pada tanggal 15 November 1991. Menempuh pendidikan Sekolah Menengah Kejuruan di SMK PGRI 1 Cibinong pada tahun 2009, Penulis melanjutkan pendidikan Diploma Tiga di AMIK BSI Jakarta Program Studi Manajemen Informatika dan menyelesaikannya pada tahun 2012. Kemudian, Penulis melanjutkan kembali Pendidikan Strata Satu di STMIK Nusa Mandiri dengan memperoleh gelar Sarjana Komputer pada tahun 2013. Selanjutnya penulis melanjutkan pendidikan S2 Komputer di STMIK Nusa Mandiri dan memperoleh gelar Magister 
Komputer pada tahun 2016. Penulis sekarang berprofesi sebagai Dosen Tetap Program Studi Sistem Informasi pada STMIK Nusa Mandiri. Penulis dapat dihubungi melalui email : lilyani.lau@nusamandiri.ac.id

Windu gata, Pascasarjana Ilmu Komputer STMIK Nusa Mandiri Windu@nusamandiri.ac.id 